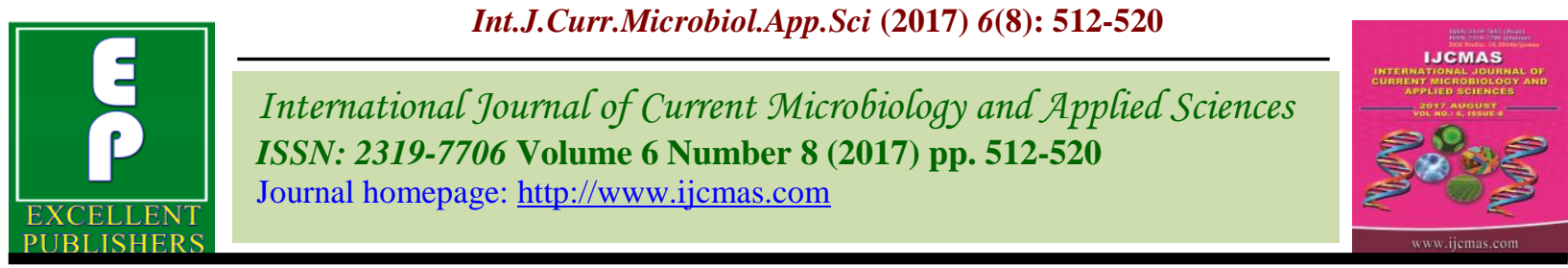

Original Research Article https://doi.org/10.20546/ijcmas.2017.608.066

\title{
Delineation of Areas Deficient for Micronutrients in Soils of Chittoor District, India
}

\author{
E. Govardhan ${ }^{1 *}$, M.C. Patnaik ${ }^{2}$, P. Surendra Babu ${ }^{2}$, A. Srinivas ${ }^{3}$ and M. Shankar ${ }^{2}$ \\ ${ }^{1}$ Department of Soil Science and Agricultural Chemistry, PJTSAU, Rajendra Nagar, \\ Hyderabad 500 030, India \\ ${ }^{2}$ AICRP on Micronutrients, PJTS Agricultural University, Rajendra Nagar, Hyderabad 500030 \\ ${ }^{3}$ Director of ARI farm, India \\ *Corresponding author
}

\section{A B S T R A C T}

\begin{tabular}{|l|}
\hline Ke y w o r d s \\
Deficient for \\
micronutrients, \\
Soils, \\
Sulphur \\
deficiency. \\
\hline Article Info \\
\hline $\begin{array}{l}\text { Accepted: } \\
\text { 04 June } 2017 \\
\text { Available Online: } \\
\text { 10 August } 2017\end{array}$ \\
\hline
\end{tabular}

\begin{abstract}
The soils of Chittoor district was found to be suffering from one or other or combination of two or more micronutrients in 324 out of analysed 576 samples and constituted 56 per cent ( $\mathrm{Zn}$ alone in 103, Fe in 40, B in 60, $\mathrm{Mn}$ in 5, $\mathrm{Cu}$ in 5 and multi micronutrient deficiencies in 107 samples). Among individual nutrients, the soils of Chittoor were found to be deficient in available zinc to an extent of 33 per cent and boron in $21 \%$ samples. The iron deficiency in the district was found to be 19 per cent followed by copper in 4 and manganese in 2.6 per cent of samples. The sulphur deficiency in the district's soils was found to be 18 per cent. The NI values for different micronutrients and sulphur in soils of Chittoor district was found to be 1.77 (medium) for $\mathrm{Zn}, 2.24$ (medium) for $\mathrm{B}, 2.26$ (medium) for $\mathrm{Fe}, 2.74$ (high) for $\mathrm{Cu}, 2.82$ (high) for $\mathrm{Mn}$ and 2.54 (high) for $\mathrm{S}$. The correlation coefficients were worked out for various parameters studied in the investigation. All the thematic maps related to studied micronutrients and sulphur were prepared in GIS environment and presented.
\end{abstract}

\section{Introduction}

Soil nutrient fertility assessment is an important pre requisite for scientific fertilizer recommendation and usage both at micro and macro level. The validity and usefulness of generated soil fertility maps of an area depends upon the intensity of sampling done, methods of analysis and classes of fertility adopted, time lapse since its preparation and the backed-up fertilizer prescription accuracy for adoption by farmers. Unlike in the recent past, where soil fertility mapping is done manually, the kind of information derived from such fertility data now is enormous due to use of tools like GIS. This facility coupledwith gathering of information such as co-ordinates of sampled area with GPS is an additional feature to re-visit the places of sampling during re-assessments of fertility.

The district of Chittoor in A.P is one whose soil fertility mapping, especially for sulphur and micronutrients was attempted for finding out the extent of deficiency of $\mathrm{S}, \mathrm{Zn}, \mathrm{Cu}, \mathrm{Fe}$, $\mathrm{Mn}$ and $\mathrm{B}$ in soil of Chittoor district of Andhra Pradesh. 


\section{Materials and Methods}

\section{Soil sampling, analysis and preparation of deficiency maps}

The methodology adopted was, about 7 to 10 soil samples were collected from each mandal. The samples were collected from cultivated lands on grid basis; as a result, the spatial coverage of survey area will be more. Accordingly, 576 soil samples were collected from 64 mandals of 66 mandals present in the district. The depth of the soil sampling was 0 $15 \mathrm{~cm}$. The soil samples collected were processed and analysed for available sulphur and micronutrients. Nutrient index value calculated from the proportion of soils under low, medium and high available nutrient categories, as represented by

$\mathrm{NIV}=$

$$
\left(\left(\mathrm{P}_{\mathrm{H}} * 3\right)+\left(\mathrm{P}_{\mathrm{M}} * 2\right)+\left(\mathrm{P}_{\mathrm{L}} * 1\right)\right)
$$

\section{0}

The index values are rated in to various categories viz., high (>2.33), medium (1.66 2.33) and low $(<1.66)$ for fertility rating (Ramamoorthy et al., 1969). Simple correlations were carried out between the soil available micronutrients and soil properties to determine the relationship between these parameters using standard procedures at central computer facility of the university using in built software.

\section{Results and Discussion}

\section{Available sulphur}

Sulphur content ranged from 3.5 to $194 \mathrm{mg} \mathrm{kg}^{-}$ ${ }^{1}$ with mean of $29.4 \mathrm{mg} \mathrm{kg}^{-1}$ and 18 per cent (104 no) analyzed soils in Chittoor district were found to be deficient in available sulphur. The mean sulphur content was in the range of 8.6 to $58.1 \mathrm{mg} \mathrm{kg}^{-1}$ with in the mandals. The extent of sulphur deficiency within the mandals ranged from 10 to 71 per cent among their soils (Table 1). The analyzed soil samples show sulphur deficiency to an extent of 50 per cent (Munaswamy, 1991; Venkatesu, 1993). As many as 26 mandals out of 64 in the district have not registered any sulphur deficiency in their soils. The NI values for available sulphur in different mandals of the district ranged from 1.29 (Buchinadu kandriga) to 3.0. Only 5 mandals of the district registered low NI values and they are irpedu, Bucchinadu kandriga, Thotembeedu, Ramachandrapuram and Chinnagottikallu. The overall NI value for sulphur of Chittoor district was found to be high (2.54) (Table 2 and Map 1).

The available sulphur of Chittoor district soils was found to be significantly and positively correlated with EC and available boron content of the same soils. It was also found to be negatively correlated with available copper of the soils $(-0.085)$.

\section{DTPA-extractable zinc}

The available (DTPA-TEA-CaCl 2 extractant) zinc status in soils of Chittoor district was found to be in the range of from 0.19 to 5.83 $\mathrm{mg} \mathrm{kg}^{-1}$ with a mean of $0.91 \mathrm{mg} \mathrm{kg}^{-1}$. Thirty three per cent of soils are deficient in $\mathrm{Zn}$ while in terms of mandals the zinc deficiency ranged from 0 to 100 per cent in their soils. Zinc sufficiency occurred with time in a soil of North Telangana Zone of Andhra Pradesh which might be due to continuous application of zinc sulphate (Vijaykumar et al., 1996). Similarly, the mean available zinc content in the soils of different mandals ranged from 0.34 (Narayanavanam) to $1.73 \mathrm{mg} \mathrm{kg}^{-1}$ (Irpedu). All the soils of 11 mandals in the district registered 100 per cent zinc sufficiency. The NI value for Zn fertility for Chittoor district soils was found to be medium with a value of 1.77.The district ranged from 1.00 to 2.44 and it was found that 21 mandals were under low NI, 41 under medium and 2 mandals were under high NI category. The available $\mathrm{Zn}$ in Chittoor soils was found to be 
positively and significantly correlated with that of $\mathrm{Cu}(0.399), \mathrm{Mn}(0.169)$ and $\mathrm{Fe}(0.109)$. (Table 2 and Map 2).

\section{DTPA-extractable iron}

The DTPA-TEA $-\mathrm{CaCl}_{2}$ extractable iron content in soils of Chittoor district ranged from 1.02 to $39.9 \mathrm{mg} \mathrm{kg}^{-1}$ soil. Its mean value was found to be $8.31 \mathrm{mg} \mathrm{kg}^{-1}$. The extent of iron deficiency $\left(4 \mathrm{mg} \mathrm{kg}^{-1}\right)$ in soils of Chittoor district was found to be 19 per cent (108 samples). This is in line with the observations of other studies (Katyal et al., 2003). The mean available iron content in 64 mandal soils in the district varied from 4.12 (Sathyavedu soils) to $15.15 \mathrm{mg} \mathrm{kg}^{-1}$ (Kothakota soils).The data on NI value for available iron in different mandal soils indicated that it was low in 5 mandals, medium in 31 and high in 28 mandals. The overall Chittoor district NI for iron fertility was found to be medium (2.26) (Table 2 and Map 3). The available iron content is soils of Chittoor district was found to be significantly and positively correlated with that of $\mathrm{Cu}$ positively $\left(0.287^{*}\right), \mathrm{Mn}\left(0.191^{*}\right), \mathrm{Zn}\left(0.169^{*}\right)$ and negatively with that of available boron ($0.139 *$ ) (Table 3).

\section{Hot water soluble boron}

The available boron was found to be deficient in 21 per cent of 576 soil samples analyzed from Chittoor district. Observed deficiency of boron to an extent of 28 and 32 per cent for irrigated and rainfed soils of Rajasthan (Chaudhary et al., 2004). The extent of boron deficiency in soils of individual mandals ranged from 0 to 100 per cent. Its content in the district soils ranged from 0.15 to $2.12 \mathrm{mg}$ $\mathrm{kg}^{-1}$ soil with a mean value of $0.91 \mathrm{mg} \mathrm{kg}$. The mean hot water extractable boron in soils of different mandals ranged from 0.38 (Kaligiri mandal) to $1.59 \mathrm{mg} \mathrm{kg}^{-1}$ (Nagiri). The boron fertility status of Chittoor district soils was found to be high with an NI value of 2.42.
Only 5 mandals soils viz, Kaligiri, Kothakota, Mulakalacheruvu, Tavanam palle and Thottembeedu registered low NI values of boron fertility and the remaining in the district have recorded medium to high NI ratings (Table 2 and Map 4).

The correlation coefficients worked out for available boron status of Chittoor soils with other characteristics revealed that it is significantly and negatively correlated with that of $\mathrm{P}_{2} \mathrm{O}_{5} \quad\left(-0.11102^{*}\right), \mathrm{K}_{2} \mathrm{O}\left(-0.106138^{*}\right)$, $\mathrm{Mn}\left(-0.11526^{*}\right)$ and $\mathrm{Fe}\left(-0.13932^{*}\right)$ and positively correlated with that of sulphur $\left(0.09263^{*}\right)$ (Table 3).

\section{DTPA-extractable manganese}

The soil analysis data of Chittoor district revealed that $\mathrm{Mn}$ was the least deficient micronutrient to an extent of only 2.6 per cent. About 2.0 per cent of soils are deficient in $\mathrm{Mn}$ content and the same findings were found by others also (Manoj Kumar et al., 2014; Venkata Subbaiah et al., 1995). As such, only 15 samples out of 576 registered DTPA Mn content of $<2 \mathrm{mg} \mathrm{kg}^{-1}$. Its content in the soils of the district ranged from 1.20 to 45.42 with a mean of $9.54 \mathrm{mg} \mathrm{kg}^{-1}$. The mean DTPA Mn content in different mandals ranged from 3.46 (Sathyavedu) to 25.31 .20 to 45.42 with a mean of $9.54 \mathrm{mg} \mathrm{kg}^{-1}$ (Kothakota). Only soils in thirteen mandals out of 64 have recorded Mn deficiency in the range of 7 to 25 per cent while the rest were having sufficient manganese status. Maximum Mn deficiency was noticed in the soils belonging to Nangalapuram (Table 2 and Map 5). The Manganese NI fertility value for Chittoor district soils was found to be 2.82 and categorized as high. The available $\mathrm{Fe}$ and $\mathrm{Zn}$ of Chittoor district soils were positively and negatively correlated with that of $\mathrm{Mn}$ in the same district (Table 3), at the same time available Mn was significantly and negatively correlated with EC $\left(-0.176^{*}\right)$ and available boron $\left(-0.115^{*}\right)$ of the same soils. 
Table.1 Mean contents of $\mathrm{S}$ and micronutrients $\left(\mathrm{mg} \mathrm{kg}^{-1}\right)$ as influenced by different categories of $\mathrm{pH}, \mathrm{EC}, \mathrm{OC}_{2} \mathrm{P}_{2} \mathrm{O}_{5}$ and $\mathrm{K}_{2} \mathrm{O}$

\begin{tabular}{|c|c|c|c|c|c|c|c|}
\hline Sol properties & Critical limits & $\mathbf{S}$ & $\mathbf{C u}$ & Mn & $\mathbf{F e}$ & $\mathbf{Z n}$ & B \\
\hline \multirow{3}{*}{$\mathbf{p H}$} & $<6.5$ & 31 & 1.00 & 10.5 & 9.15 & 0.97 & 0.99 \\
\hline & $6.5-7.5$ & 30 & 0.94 & 9.60 & 8.92 & 0.94 & 0.88 \\
\hline & $>7.5$ & 29 & 0.88 & 8.5 & 7.94 & 0.89 & 0.90 \\
\hline \multirow{3}{*}{$\mathrm{EC}\left(\mathrm{dS} \mathrm{m} \mathrm{m}^{-1}\right)$} & $<0.5$ & 29 & 1.04 & 10.52 & 8.57 & 0.94 & 0.89 \\
\hline & $0.5-0.75$ & 35 & 0.98 & 7.93 & 7.73 & 0.92 & 1.04 \\
\hline & $>0.75$ & 43 & 0.93 & 5.58 & 7.35 & 0.85 & 0.94 \\
\hline \multirow{3}{*}{$\mathrm{OC}(\%)$} & 0.5 & 29 & 0.92 & 9.11 & 8.45 & 0.87 & 0.91 \\
\hline & $0.5-0.75$ & 29 & 0.92 & 9.28 & 8.60 & 0.94 & 0.92 \\
\hline & $>0.75$ & 35 & 1.07 & 10.6 & 8.95 & 1.07 & 0.84 \\
\hline \multirow{3}{*}{$\mathrm{P}_{2} \mathrm{O}_{5}\left(\mathrm{~kg} \mathrm{ha}^{-1}\right)$} & $<25$ & 28 & 0.84 & 10.59 & 8.51 & 1.01 & 0.99 \\
\hline & $25-59$ & 30 & 0.82 & 9.15 & 8.36 & 0.92 & 0.94 \\
\hline & $>59$ & 30 & 0.98 & 9.80 & 8.45 & 0.83 & 0.88 \\
\hline \multirow{3}{*}{$\mathrm{K}_{2} \mathrm{O}\left(\mathrm{kg} \mathrm{ha}^{-1}\right)$} & $<140$ & 36 & 0.84 & 8.30 & 8.53 & 0.81 & 1.09 \\
\hline & $140-340$ & 32 & 0.94 & 9.76 & 8.25 & 0.89 & 0.95 \\
\hline & $>340$ & 26 & 0.93 & 9.94 & 8.65 & 0.96 & 0.84 \\
\hline
\end{tabular}

Table.2 Soil available nutrient status in soils of Chittoor district of Andhra Pradesh

\begin{tabular}{|c|c|c|c|c|c|c|c|c|c|c|}
\hline \multirow[b]{2}{*}{ S NO } & \multirow[b]{2}{*}{ Element } & \multirow{2}{*}{$\begin{array}{c}\text { No of } \\
\text { samples }\end{array}$} & \multicolumn{2}{|c|}{ Status } & \multirow[b]{2}{*}{ PSD } & \multicolumn{3}{|c|}{ Sample no. in Category } & \multicolumn{2}{|c|}{ Nutrient Index } \\
\hline & & & Range & Mean & & Low & Medium & High & Value & Rating \\
\hline 1 & Sulphur & 576 & $3.5-194$ & 29.4 & 18 & 106 & 56 & 414 & 2.54 & High \\
\hline 2 & Zinc & 576 & $0.19-5.83$ & 0.91 & 34 & 188 & 325 & 63 & 1.77 & Medium \\
\hline 4 & Boron & 576 & $0.15-2.12$ & 0.91 & 20 & 119 & 103 & 354 & 2.42 & High \\
\hline 5 & Manganese & 576 & $1.20-45.4$ & 9.54 & 3 & 15 & 71 & 490 & 2.82 & High \\
\hline 6 & Copper & 576 & $0.10-4.28$ & 0.93 & 5 & 27 & 93 & 456 & 2.74 & High \\
\hline
\end{tabular}


Table.3 Correlation coefficient matrix for different soil characteristics

\begin{tabular}{|c|c|c|c|c|c|c|c|c|c|c|c|}
\hline & $\mathbf{p H}$ & $\begin{array}{c}\mathrm{EC} \\
\left(\mathrm{d} \mathrm{Sm}^{-1}\right)\end{array}$ & $\mathrm{OC}(\%)$ & $\begin{array}{c}\mathrm{P}_{2} \mathrm{O}_{5} \\
\left(\mathrm{~kg} \mathrm{ha}^{-1}\right)\end{array}$ & $\begin{array}{c}\mathrm{K}_{2} \mathrm{O} \\
\left(\mathrm{kg} \mathrm{ha}^{-1}\right)\end{array}$ & $\begin{array}{l}\mathrm{CaCl}_{2}-\mathrm{S} \\
\left(\mathrm{mg} \mathrm{kg}^{-1}\right)\end{array}$ & $\begin{array}{c}\text { DTPA- } \\
\mathrm{Cu} \\
\left(\mathrm{mg} \mathrm{kg}^{-1}\right) \\
\end{array}$ & $\begin{array}{c}\text { DTPA- } \\
\text { Mn } \\
\left(\mathrm{mg} \mathrm{kg}^{-1}\right) \\
\end{array}$ & $\begin{array}{c}\text { DTPA- } \\
\text { Fe } \\
\left(\mathrm{mg} \mathrm{kg}^{-1}\right) \\
\end{array}$ & $\begin{array}{c}\text { DTPA- } \\
\text { Zn } \\
\left(\mathrm{mg} \mathrm{kg}^{-1}\right) \\
\end{array}$ & $\begin{array}{c}\text { HW-B } \\
\left(\mathrm{mg} \mathrm{kg}^{-1}\right)\end{array}$ \\
\hline pH & 1 & 0.04443 & -0.0082 & 0.03263 & 0.03518 & 0.02758 & -0.02118 & 0.00061 & $\begin{array}{c}- \\
0.08973 *\end{array}$ & -0.02583 & -0.02836 \\
\hline $\begin{array}{c}\mathrm{EC} \\
\left(\mathrm{d} \mathrm{Sm}^{-1}\right)\end{array}$ & & 1 & $0.10871 *$ & 0.03765 & -0.03094 & $0.1523 *$ & 0.06871 & $-0.17614 *$ & -0.05067 & 0.02068 & 0.03965 \\
\hline OC $(\%)$ & & & 1 & -0.01488 & -0.00777 & -0.00703 & 0.04555 & -0.05915 & -0.00625 & 0.00533 & -0.02255 \\
\hline $\begin{array}{c}\mathrm{P}_{2} \mathrm{O}_{5} \\
\left(\mathrm{~kg} \mathrm{ha}^{-1}\right)\end{array}$ & & & & 1 & $0.08215^{*}$ & 0.05208 & 0.07983 & -0.04908 & -0.01283 & -0.04383 & $\begin{array}{c}- \\
0.11102 *\end{array}$ \\
\hline $\begin{array}{c}\mathrm{K}_{2} \mathrm{O} \\
\left(\mathrm{kg} \mathrm{ha}^{-1}\right)\end{array}$ & & & & & 1 & -0.10927 & 0.02224 & 0.03199 & 0.06655 & 0.0347 & $\begin{array}{c}- \\
0.10613 *\end{array}$ \\
\hline $\begin{array}{l}\mathrm{CaCl}_{2}-\mathrm{S} \\
\left(\mathrm{mg} \mathrm{kg}^{-1}\right)\end{array}$ & & & & & & 1 & $\begin{array}{c}- \\
0.08507 *\end{array}$ & $-0.09521 *$ & -0.07543 & -0.04738 & $0.09263 *$ \\
\hline $\begin{array}{l}\text { DTPA-Cu } \\
\left(\mathrm{mg} \mathrm{kg}^{-1}\right)\end{array}$ & & & & & & & 1 & 0.05864 & $0.28734 *$ & $0.39946^{*}$ & -0.05043 \\
\hline $\begin{array}{l}\text { DTPA- } \\
\mathrm{Mn} \\
\left(\mathrm{mg} \mathrm{kg}^{-1}\right)\end{array}$ & & & & & & & & 1 & $0.19124 *$ & $0.16998 *$ & $\stackrel{-}{0.11526 *}$ \\
\hline $\begin{array}{l}\text { DTPA-Fe } \\
\left(\mathrm{mg} \mathrm{kg}^{-1}\right)\end{array}$ & & & & & & & & & 1 & $0.10881 *$ & $\begin{array}{c}- \\
0.13932 *\end{array}$ \\
\hline $\begin{array}{l}\text { DTPA-Zn } \\
\left(\mathrm{mg} \mathrm{kg}^{-1}\right)\end{array}$ & & & & & & & & & & 1 & -0.01928 \\
\hline $\begin{array}{c}\text { HW-B } \\
\left(\mathrm{mg} \mathrm{kg}^{-1}\right)\end{array}$ & & & & & & & & & & & 1 \\
\hline
\end{tabular}

$*$ Significant at $5 \%$ 
Map.1 Spatial variation in available sulphur deficiency status in soils of Chittoor district of Andhra Pradesh

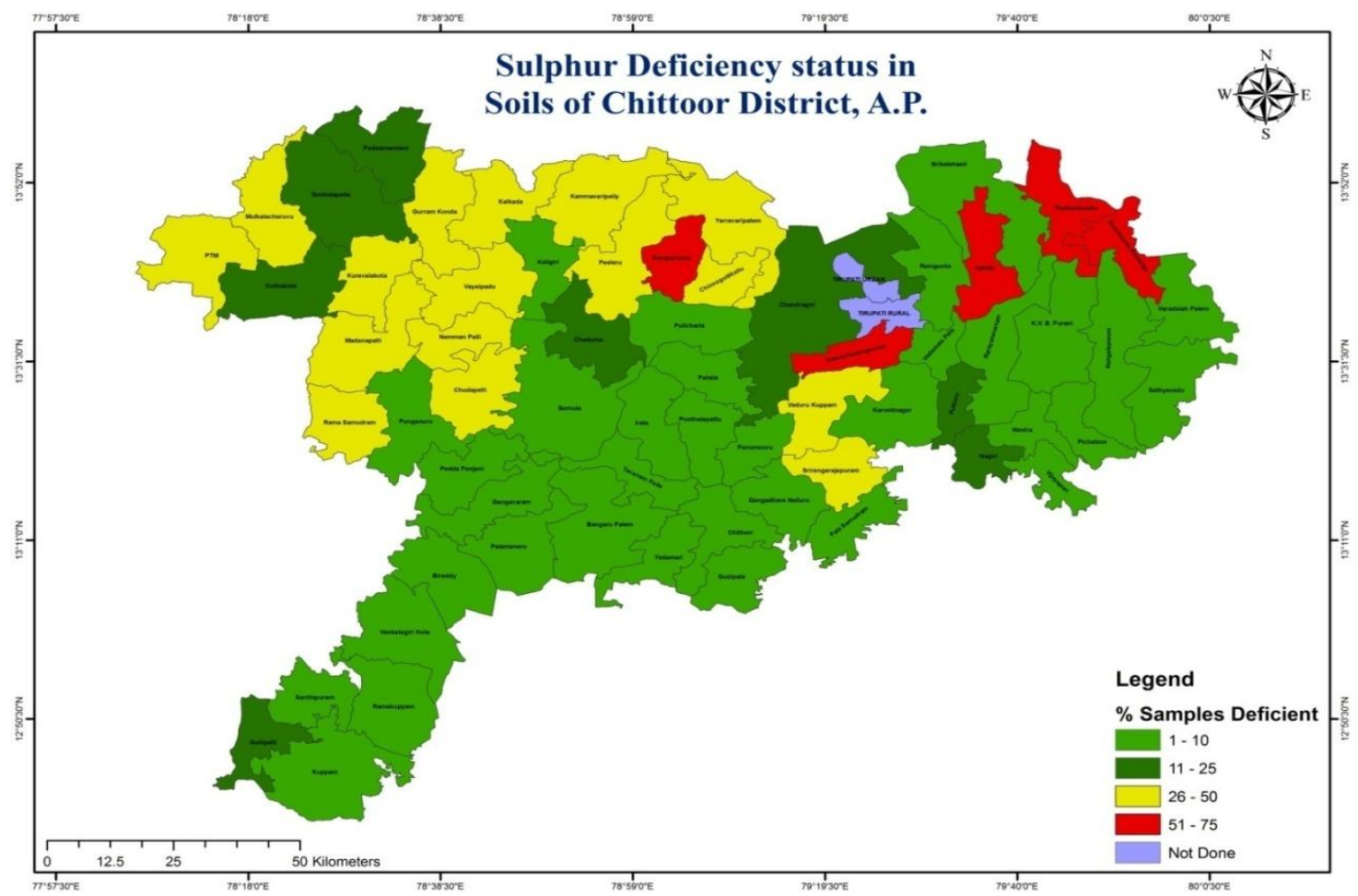

Map.2 Spatial variation in DTPA-extractable Zn deficiency status in soils of Chittoor district of AndhraPradesh

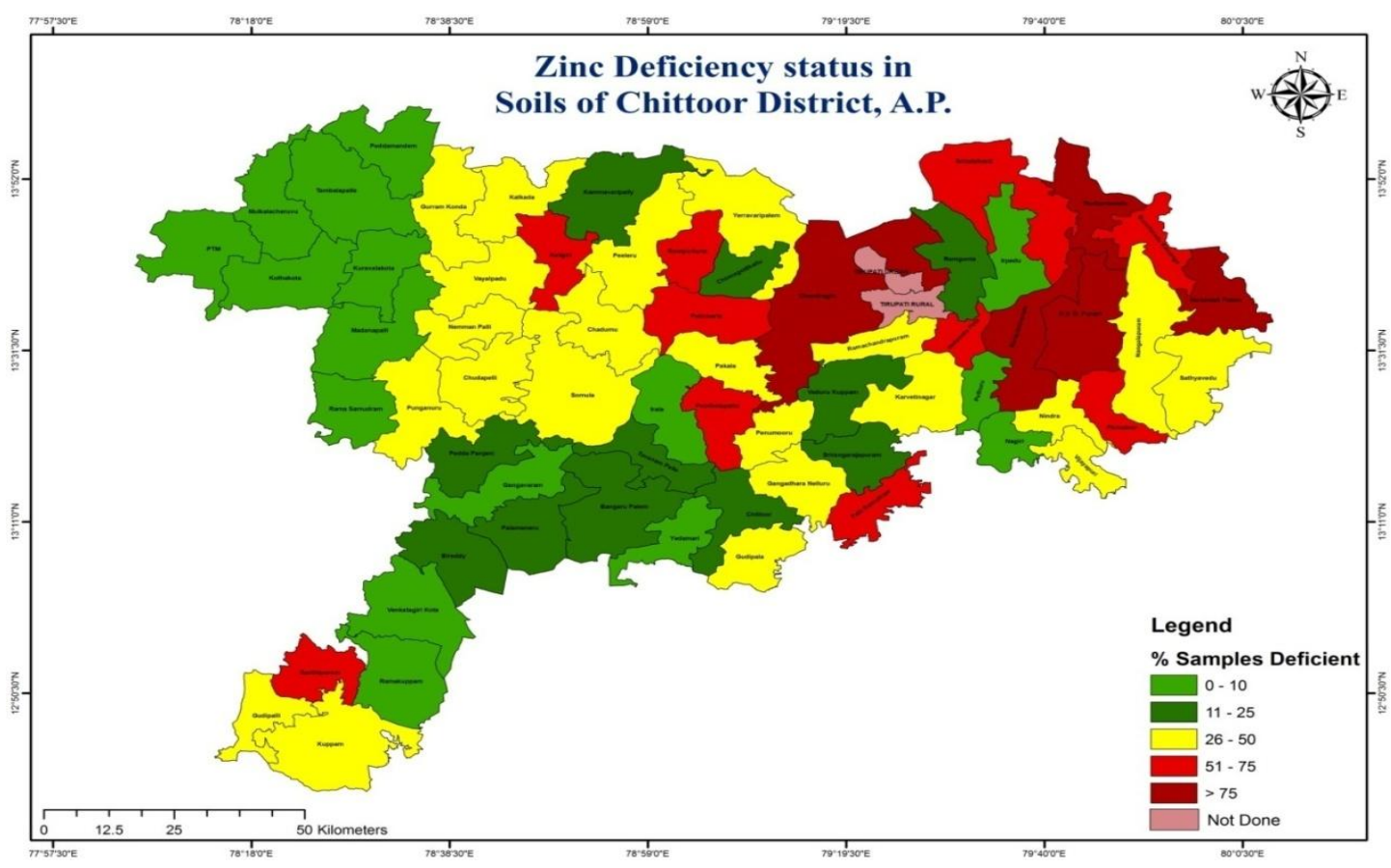


Map.3 Spatial variation in DTPA-extractable Fe deficiency status in soils of Chittoor district of AndhraPradesh

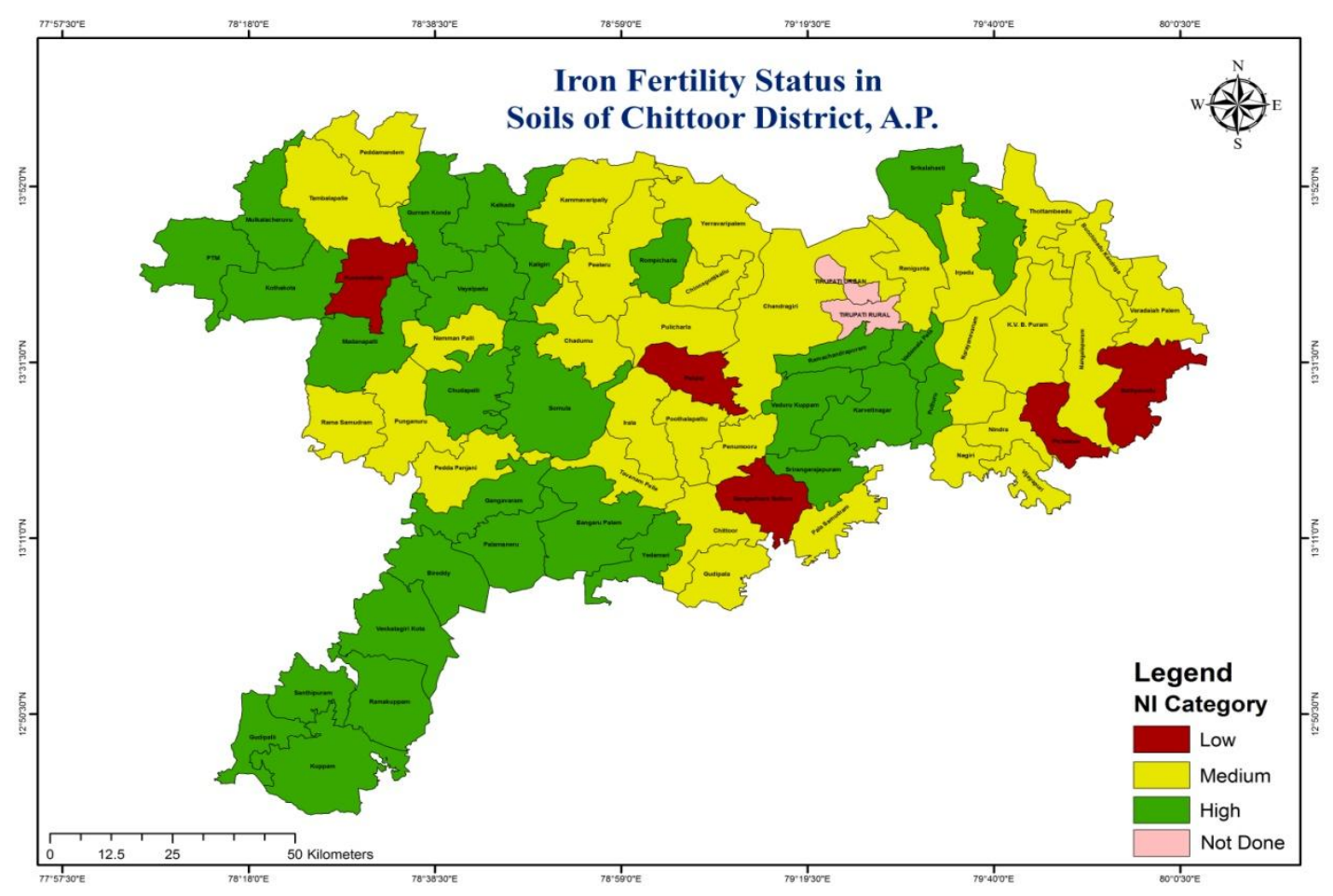

Map.4 Spatial variation in hot water soluble boron deficiency status in soils of Chittoor district of AndhraPradesh

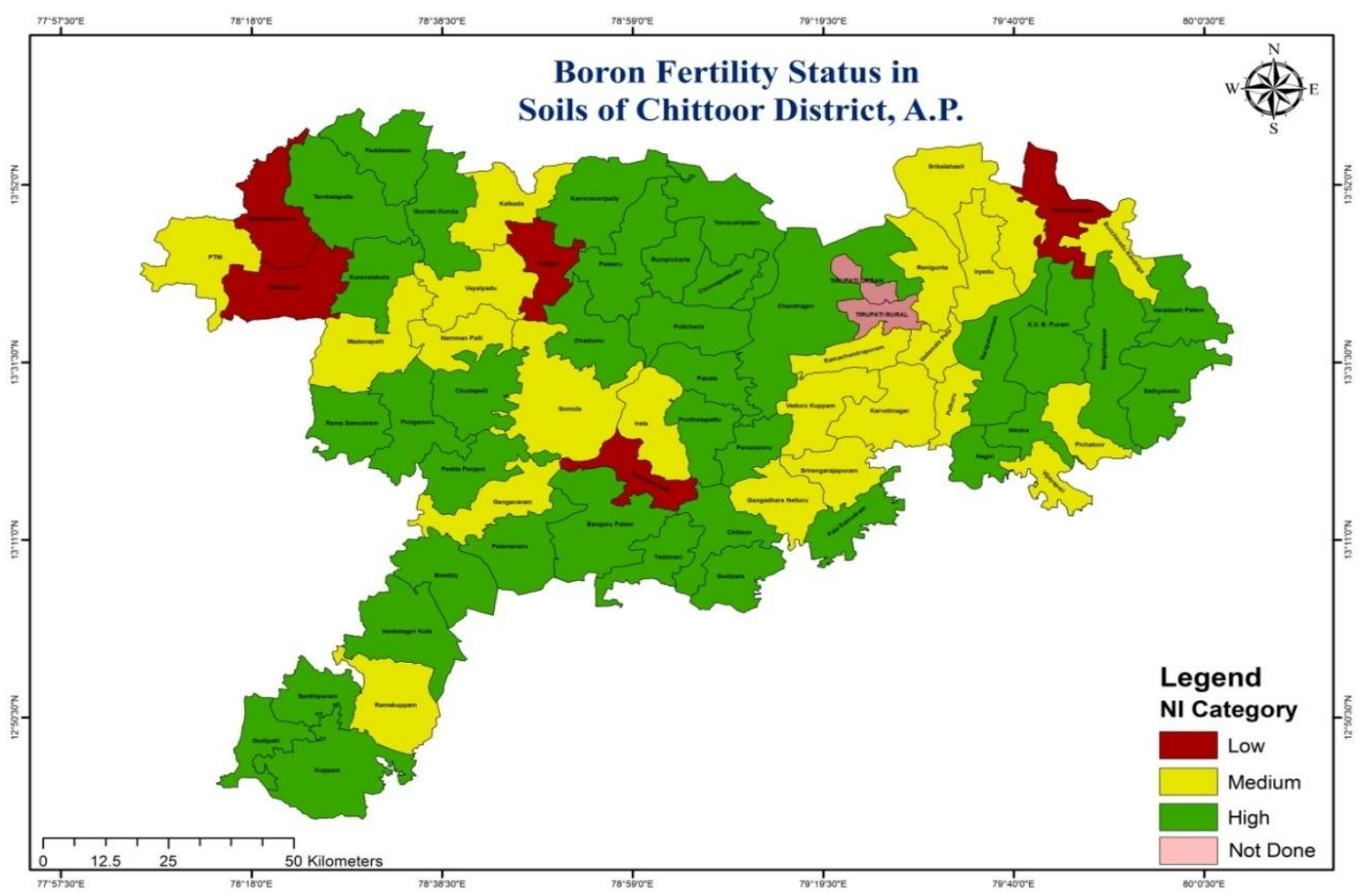


Map.5 Spatial variation in DTPA-extractable Mn deficiency status in soils of Chittoor district of AndhraPradesh

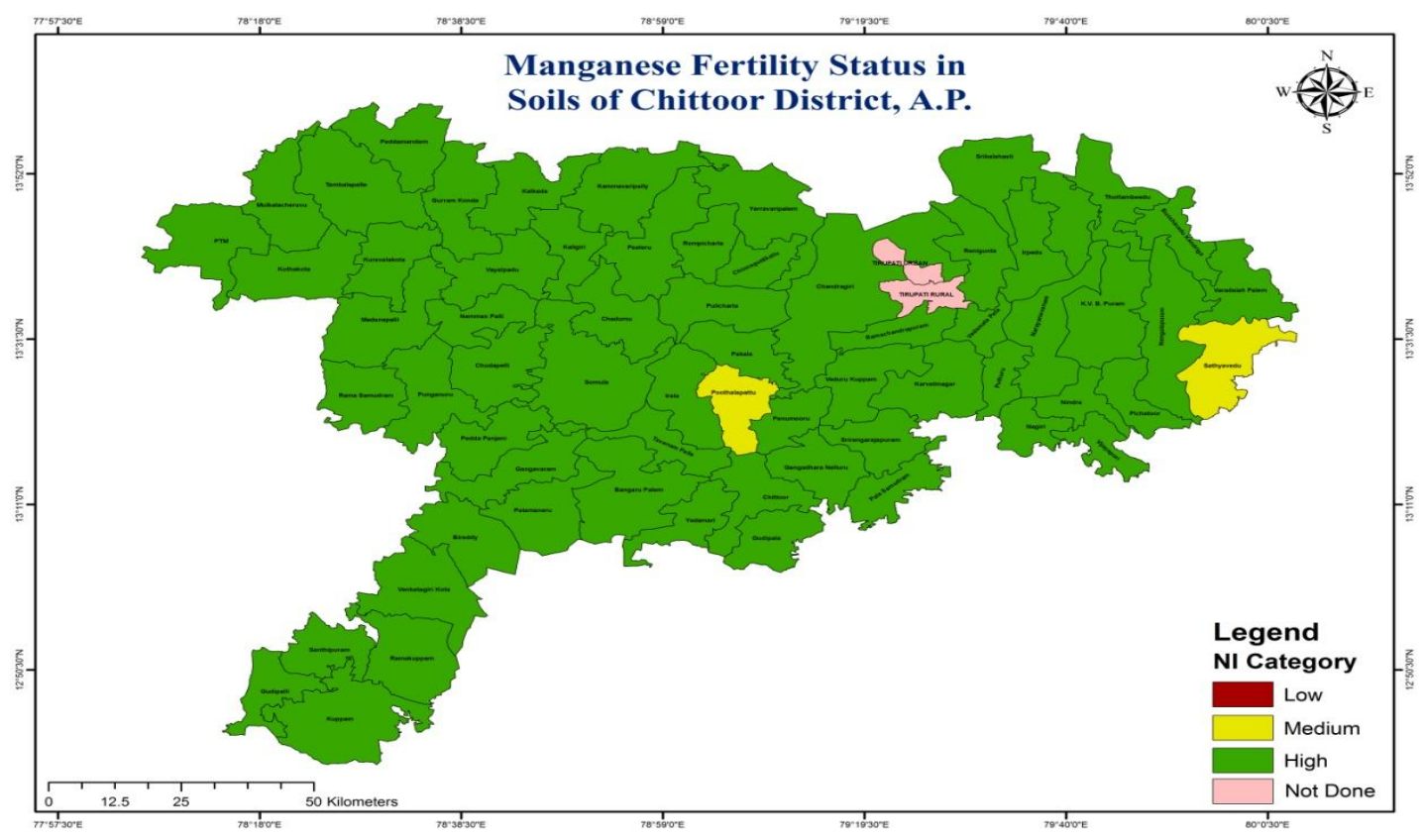

Map.6 Spatial variation in DTPA-extractable Cu deficiency status in soils of Chittoor district of AndhraPradesh

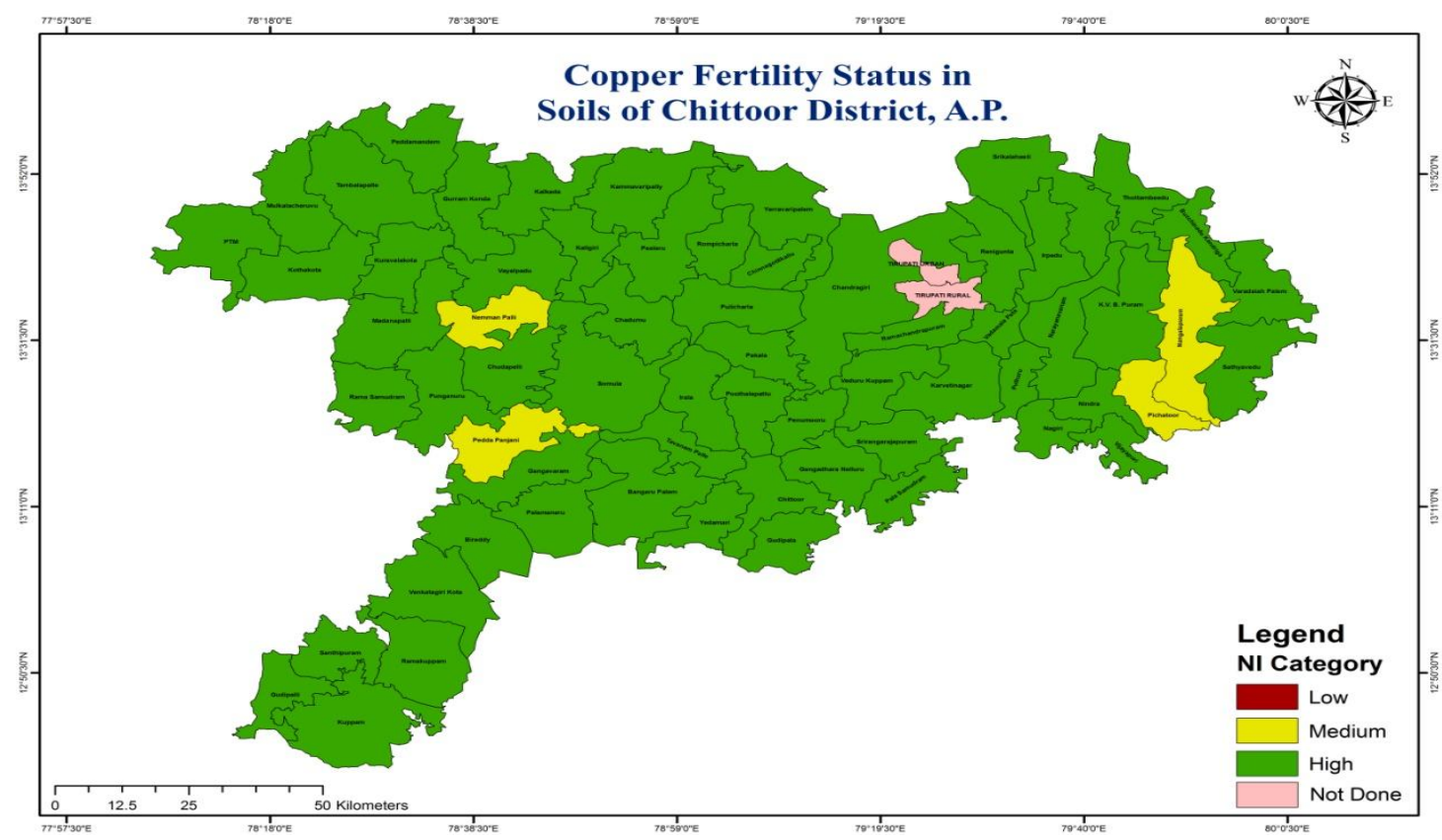

\section{DTPA-extractable copper}

The DTPA-extractable copper status of the soils of Chittoor district ranged from deficient to sufficient $\mathrm{Cu}$ status $\left(0.10\right.$ to $\left.4.28 \mathrm{mg} \mathrm{kg}^{-1}\right)$ with a mean of $0.93 \mathrm{mg} \mathrm{kg}^{-1}$. The highest available $\mathrm{Cu}$ was recorded in Karvetnagar (4.28 $\mathrm{mg} \mathrm{kg}^{-1}$ ). 
Similarly, lowest $\mathrm{Cu}$ content was found in the soils of Pedda Panjani and Tanvanam Palle mandals. Only 26 samples in Chittoor district were found to be deficient $4 \%$ and rest of 96 per cent of samples collected (550 no) were sufficient in available copper content (Table 2 and Map 6). The mean copper content among different mandals ranged between 0.37 (Nangalapuram) to 1.85 (Puthuru) $\mathrm{mg} \mathrm{kg}^{-1}$. Maximum copper deficiency (50\%) was noticed in Pedda panjani mandal followed by Nemman palli (29\%). The soils collected from all the 64 mandals except eighteen mandals are sufficient in copper. The district Copper fertility NI value was 2.74 and was rated as high.

In conclusion, generalized nutrient recommendations over large areas may lead to the possibility of over or under use of micronutrients with adverse economic and environmental challenges. The precision nutrient management concept is expected to provide ways to suitable micronutrient management. GIS maps based on intensive soil sampling are useful to assess variability in distribution of native micronutrients and in developing site-specific management practices for optimizing yield without any adverse effect on environment. The frequency distribution of micronutrients would further, aid in developing precise recommendation based on native nutrients status and crop need. Soil micronutrients maps would be highly useful in improving our understanding regarding native and extent of micronutrient problems and this can aid in developing appropriate micronutrients management strategies leading to better yield and environmental stewardship, which ultimately would be helpful in determining their relationship with animal and human health.

\section{References}

Chaudhary, D.R. and Shukla, L.M. 2004. Boron status of arid soils of Western Rajasthan in relation to their characteristics. J. Indian Society of Soil Sci., 52: 194-196.

Katyal, J.C. and Rattan, R.K. 2003. Secondary and micronutrients research gaps and future needs. Fertilizer News, 48: 9-14.

Manoj Kumar, Jatav, M.K., Dua, V.K., Trehan, S.P., Lal S.S and Upadhyay, N.C. 2014. Methodology to map spatial variability of available nutrients in area of intensively growing potato (Solanum tuberosum) using remote sensing and GIS. Indian J. Agri. Sci., 84(3): 396-400.

Munaswamy, V. 1991. Secondary nutrient status of groundnut growing soils of Chittoor district of Andhra Pradesh. M.Sc (Ag). Thesis submitted to Andhra Pradesh Agricultural University, Hyderabad.

Ramamoorthy, B. and Bajaj, J.C. 1969. Available $\mathrm{N}, \mathrm{P}$ and $\mathrm{K}$ status of Indian soils. Fertilizers News, 14: 24-26.

Venkata Subbaiah, V., Muralidharan, K., Patnaik, M.C and Bhupal Raj, G.1995. Micronutrients. Solis of Andhra Pradesh, A Monograph. Pp. 63-98.

Venkatesu, T. 1993. Distribution and availability of cationic Micronutrients in Groundnut grown sandy soils of Nellore district, M.sc thesis submitted to, Andhra Pradesh Agricultural University, Hyderabad.

Vijaykumar, T., Suryanarayan Reddy, M. and Gopalakrishna, V. 1996. Vertical distribution of micronutrient cations in some soil profiles in northern Telangana of Andhra Pradesh. J. Indian Soc. Soil Sci., 44(2): 328-330.

\section{How to cite this article:}

Govardhan, E., M.C. Patnaik, P. Surendra Babu, A. Srinivas and Shankar, M. 2017. Delineation of Areas Deficient for Micronutrients in Soils of Chittoor District, India. Int.J.Curr.Microbiol.App.Sci. 6(8): 512-520. doi: https://doi.org/10.20546/ijcmas.2017.608.066 